\title{
Histopathological study of spleen infected by Marek's Disease Virus (MDV) in broiler chicken
}

A. Khan, N. Khatoon*, M. Akram, Noor-un-Nisa, A. Khan and S. Waheed

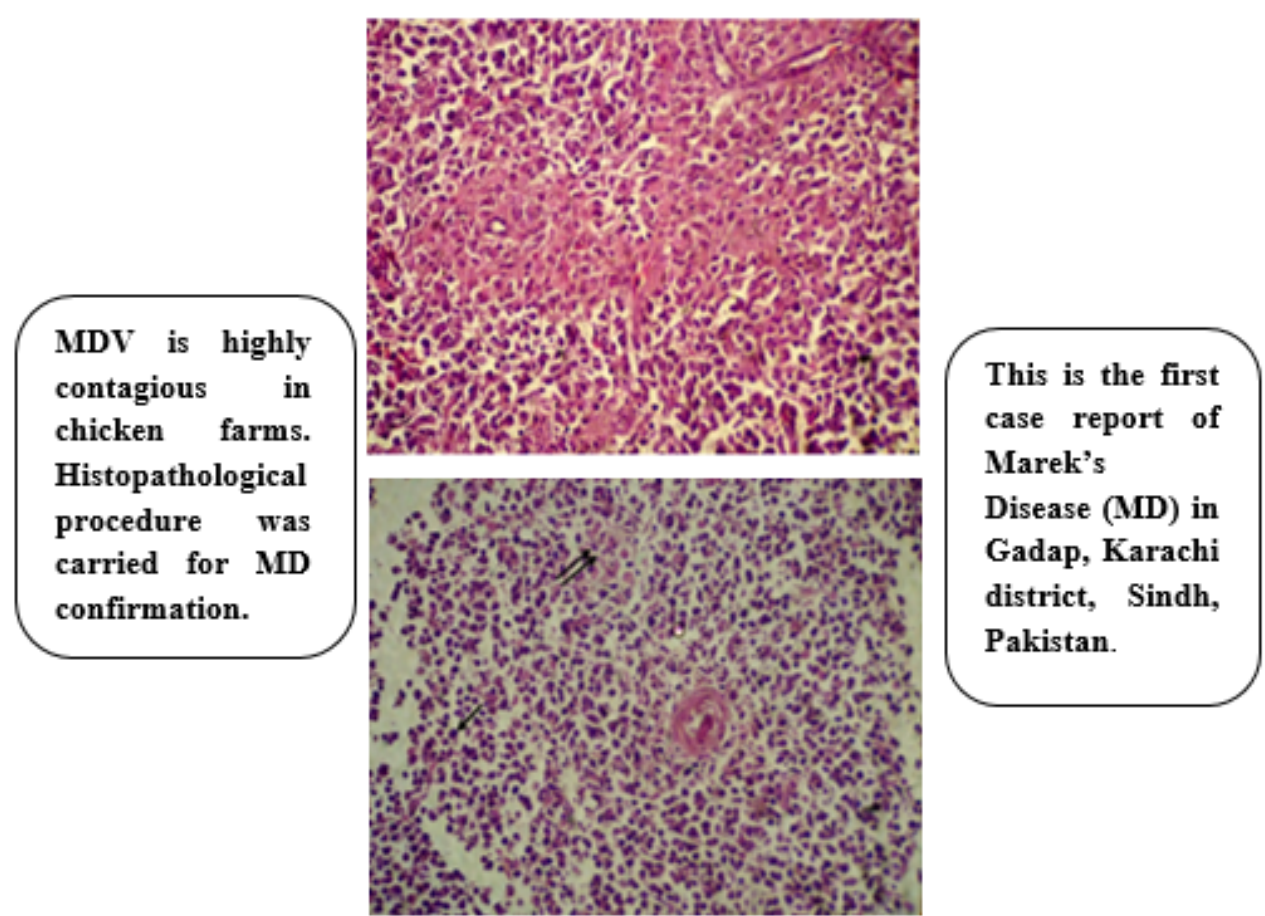

Section of Broiler chicken spleen infected with MDV showing lymphocytes of various sizes alongwith immature cells.

\section{Highlights}

- The spleen of infected birds 6-10 weeks old were obtained from a broiler chickens in poultry estate, Gadap, Karachi district, Sindh, Pakistan.

- On histopathological examination, lymphoid cells of small, medium and large sized, lymphoblasts and immature cells were observed.

- This is the first case report of Marek's Disease Virus (MDV) in broiler chicken from Gadap, Karachi district, Sindh, Pakistan. 
SHORT COMMUNICATION

\title{
Histopathological study of spleen infected by Marek's Disease Virus (MDV) in broiler chicken
}

\author{
A. Khan ${ }^{1}$, N. Khatoon ${ }^{2, *}$, M. Akram ${ }^{3}$, Noor-un-Nisa ${ }^{4}$, A. Khan ${ }^{5}$ and S. Waheed ${ }^{2}$ \\ ${ }^{1}$ CDRI, Pakistan Agricultural Research Council, University of Karachi, Karachi-75270, Pakistan. \\ ${ }^{2}$ Department of Zoology, University of Karachi, Karachi-75270, Pakistan. \\ ${ }^{3}$ Micro laboratories, 522 Anam blessings, Shahra-e-Faisal, Karachi-75350, Pakistan. \\ ${ }^{4}$ Vertebrate Pest Control Institute, SARC, Karachi University Campus, Karachi, Pakistan. \\ ${ }^{5}$ Department of Microbiology, University of Karachi, Karachi-75270, Pakistan.
}

Received: 28/11/2019; Accepted: 01/02/2021

\begin{abstract}
Marek's disease virus (MDV) is highly contagious in chicken farms and is a cell-associated oncogenic herpesvirus. The gross morphology and histopathological characteristics of neoplasm are one of the important components of diagnosis. The spleen of infected birds 6-10 weeks old were obtained from a broiler chickens in poultry estate, Gadap, Karachi district, Sindh. On histopathological examination lymphoreticular infiltrations of neoplastic cells were seen under high magnification. A number of atrophied cells and extensive inflammatory reaction was present. Lymphoid cells of various sizes, lymphoblasts and immature cells were observed. Necrotic foci and haemorrhages were present. In some slides focal pleomorphic cell proliferation was obvious. Besides neoplastic lymphocytic aggregation and dysplastic foci were observed.
\end{abstract}

Keywords: Marek's disease; broiler chicken; spleen; Gadap; Sindh; Pakistan.

\section{INTRODUCTION}

Marek's disease (MD) is a neuropathic and lymphoproliferative disease in chicken which is caused by Marek's disease virus (MDV) (Herpesviridae). It is highly contagious in poultry farms and is a cell-associated oncogenic herpesvirus. It is still difficult to develop strategies for the control of Marek's disease. The clinical symptoms of MD and the presence of lymphomas are affected by the immune response. Virus is maintained in latent form in resistant chicken while in the susceptible birds the infection causes lymphomas (Kaiser et al., 2003). Witter et al. (1973) suggested that the age of the birds is important at the time of virus exposure although chicken of all ages are susceptible to the infection but the frequency of lymphomas in older bird is far less when compared to young birds. MD gross lesions are characterized by diffuse enlargement of spleen and liver. Lymphomatous lesions in visceral organs are uniformly proliferative in nature (Nabinejad, 2013). Haq et al. (2002) and Moryani et al. (2020) have reported Marek's from Punjab and Sindh, Pakistan. Wen et al. (2018) reported that the etiology of tumors in egg laying chicken which were previously vaccinated against Marek's disease virus. In India
Kannaki and Gowthaman (2020) suggested that Marek's disease is one of the emerging disease in Indian Poultry causing almost 10 - 40\% mortality. In China Sun et al. (2017) reported that MD virus was continuously evolving resulting in increasing failure of vaccination. The aim of this study was the investigation of spleen of infected birds from poultry estate, Gadap, Sindh. Since gross lesions in spleen can be dubious, proper histopathological study is important.

\section{MATERIALS AND METHODS}

The poultry farm studied was located in poultry estate, Gadap $\left(25.0023^{\circ} \mathrm{N}, 67.1321^{\circ} \mathrm{E}\right)$, Karachi district, Sindh, Pakistan. Gadap is located $46.8 \mathrm{~km}$ from Karachi and has 82 poultry farms in an area of $3.5 \mathrm{~km}$. The farms stock was comprised of 8,000 birds, and all broilers were divided into 4 flocks. One hundred and ten birds had complete paralysis of wings and legs and diarrhea while fifty two had partial paralysis of wings. All autopsied birds had complete paralysis. The affected chickens had been vaccinated with HVD subcutaneously along with IB (Infectious Bronchitis), IBD (Infectious Bursal Disease) and New castle intraocularly at first day of age. On examination, a number of lesions were prominent in the viscera especially in the spleen, these spleens showed complete discolouration in three birds from 103 autopsied of 6 - 10 weeks old birds. The spleen was carefully removed with the help of a sharp scissor and forceps and kept in 10\% formalin for 3 days and transferred to glass vials and then send to Parasitology section, Department of Zoology, University of Karachi. The spleen tissue was dehydrated in different concentrations of ethanol and embedded in paraffin wax at $52{ }^{\circ} \mathrm{C}$ for 4 days, $10 \mu \mathrm{m}$ sections were stained with haematoxylin and eosin (H \& E) (Luna, 1968). In all the three chickens, lesions were greyish white in colour with necrosis and haemorrhages present in the spleen which was soft and discoloured either just below the skin or in deeper tissue. Gross lesions, despite being important characteristic of Marek's disease were processed further for histopathological examination for MD confirmation. 


\section{Ethical clearance}

The poultry farmers had taken permission from the animal house, Department of Zoology, University of Karachi, so that any sort of disease may not spread in the poultry farms. They had given live birds which were later dissected and portion of spleen was removed for further processing. The ethical clearance certificate number is 1671/ZAH/20.

\section{RESULTS AND DISCUSSION}

The histopathology of spleen at higher magnification showed a number of small, medium sized lymphocytes along with the pulp composed of reticular cell indicating extensive inflammatory reaction (Figure 1). Lymphocytes cells of various sizes along with lymphoblast and immature cells were prominent (Figure 2). Initial stage of tumour formation with necrotic foci and haemorrhages was observed (Figure 3). Marek's disease had caused muscle tumour along with pleomorphic cell proliferation was prominent (Figure 4). Neoplastic lymphocytic aggregates and dysplastic foci were obvious (Figure 5).

In avian leucosis, Schat and Nair (2008); Akram et al.

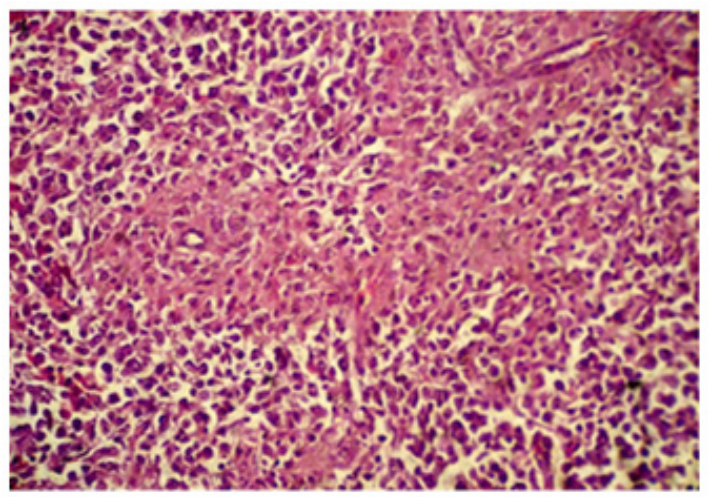

Figure 1: Photomicrograph of chicken spleen with small, medium and large sized lymphocyte along with white pulp composed of reticular cells which indicates extensive inflammatory reaction $(\times 400)$.

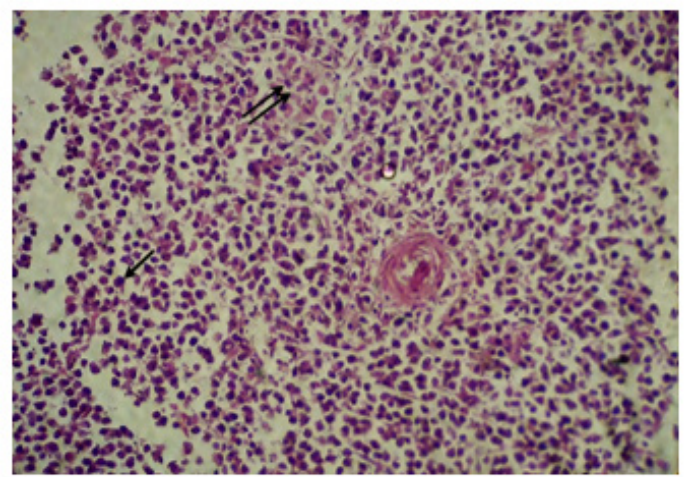

Figure 2: Photomicrograph showing lymphoid cells of various sizes. Lymphoblasts (arrow) and immature cells (double arrow) were prominent $(\times 400)$.

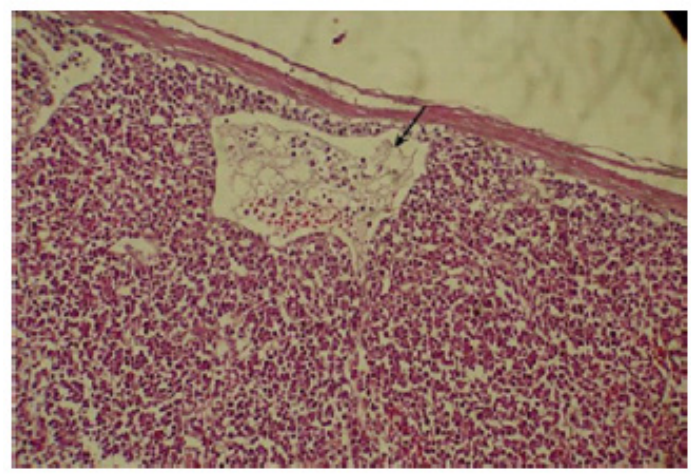

Figure 3: Photomicrograph showing initial stage of tumour formation with necrotic foci and haemorrhages $($ arrow $)(\times 200)$. 


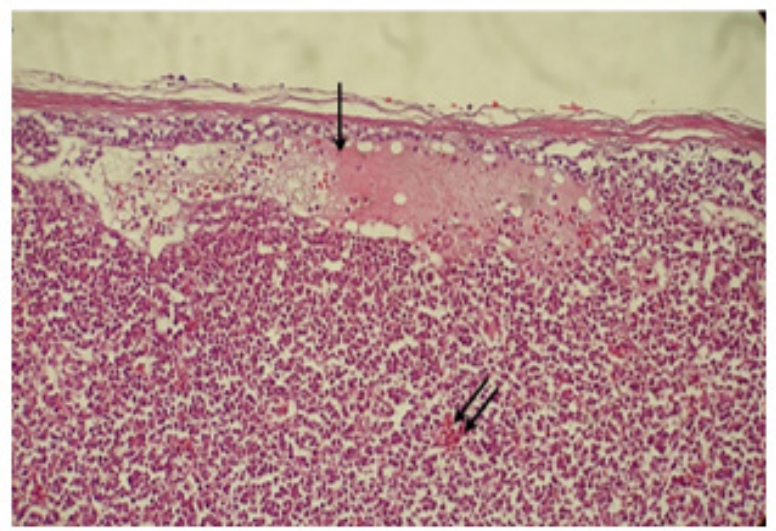

Figure 4: Photomicrograph showing muscle tumour (arrow) due to Marek's disease along with focal pleomorphic cell proliferation (double arrow) $(\times 200)$.

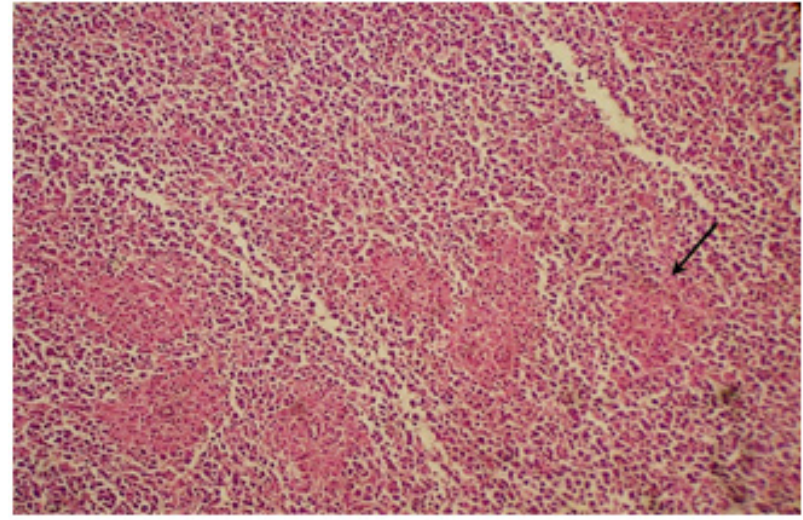

Figure 5: Photomicrograph of spleen showing neoplastic lymphocytic aggregates and dysplastic foci (arrow) $(\times 200)$.

(2012) had reported similar gross characteristics of spleen, thus histopathology seems to be one of the important tools for confirmation of the Marek's disease.

Earlier, Schat (1981) observed that in splenectomised (Sx) chicken, the spread of Marek's disease had been delayed by six to seven days after intratracheal exposure and visceral tumours decreased but degree of protection by vaccination with a oncogenic virus SB-1 was not influenced. Islam et al. (2001) reported that spleen tissue and peripheral blood lymphocytes (PBL) were found to provide similar sensitivity of detection of Marek's disease virus with a slight advantage in favour of spleen by polymerase chain reaction (PCR).

Nair (2018) had suggested that the acquired control of Marek's disease virus is mainly through vaccination with live attenuated vaccines although improvement in genetic resistance of birds is also important component of disease control. It has been observed that continuous evolution of virulence and appearance of hypervirulent pathotypes remains the major trial for sustainable control of this disease.

In the present study, although the flock of birds were vaccinated on the first day of age, yet the occurrence of Marek's disease virus may be due to poor biosecurity conditions as earlier observed by Fossum et al. (2009), on the other hand since only few birds were infected, the slow progress of Marek's disease in this particular case may be due to vaccination. This is the first case report of MDV in broiler chicken from Gadap, Karachi district, Sindh, Pakistan. Proper vaccination and proper bio-security conditions are highly effective in eradicating MDV. In future studies PCR along with its modified LAMP (Loop mediated isothermal amplification) shall be used for better understanding of MDV.

\section{CONCLUSION}

Marek's disease is a neuropathic lymphoproliferative disease in chicken caused by Marek's disease virus (Herpesviridae). The affected chickens had been vaccinated with HVD subcutaneously along with IB, IBD and New castle intraocularly at first day of age. On examination a number of lesions were prominent in spleen showed complete discolouration of spleen. Histopathology was carried out to observe the changes caused by Marek's disease virus. The major changes observed were lymphocytes of various sizes were seen along with lymphoblast and immature cells were prominent while muscle tumour along with pleomorphic cell proliferation was prominent. This is the first case report of MDV in Broiler chicken from Gadap, Karachi district, Sindh, Pakistan.

\section{ACKNOWLEDGEMENT}

We are thankful to Mr. Mohsin for his help in dissecting the viscera. 


\section{DECLARATION OF CONFLICT OF INTEREST}

The authors declare that they have no conflicts of interest pertaining to this study.

\section{REFERENCES}

Akram, M., Khan, A., Khatoon, N., Noor-un-Nisa. and Sayed, M. (2012). Lymphoid leucosis in chicken Histopathology of spleen. Pakistan Journal of Zoology 44(2): 596-597.

Fossum, O., Jansson, D.S., Etterlin, P.E. and Vågsholm, I. (2009). Causes of mortality in laying hens of different housing systems in 2001 to 2004. Acta Veterinaria Scandinavica 51(3): 1-9. DOI: 10.1186/1751-0147-513.

Haq, A.U., Siddique, M. and Iqbal, Z. (2002). Epidemiological study of marek's disease in commercial layer flocks in district Toba Tek Singh, Pakistan. Pakistan Veterinary Journal 21(4): 198-201.

Islam, A.F.M.F., Walkden-Brown, S.W., Burgess, S.K. and Groves, P.J. (2001). Marek's disease on broiler chickens: effect of route of infection and herpesvirus of turkey-vaccination status on detection of virus from blood or spleen by polymerase chain reaction, and on weights of birds, bursa and spleen. Avian Pathology 30(6): 621-628. DOI: 10.1080/03079450120092116.

Kaiser, P., Underwood, G. and Davison, F. (2003). Differential cytokine response following Marek's disease virus infection of chicken differing in resistance to Marek's disease. Journal of Virology 77(1): 762-768. DOI: 10.1128/JVI.77.1.762.768.2003.

Kannaki, T.R. and Gowthaman, V. (2020). Marek's disease: time to review the emerging threat in Indian Poultry. World's Poultry Science Journal 76(1): 91-99. DOI: 10.1080/00439339.2020.1729674.

Luna, L.G. (1968). Manual of the Histologic Staining Methods of the Armed Forces Institute of Pathology. $3^{\text {rd }}$ ed., New York: McGraw Hill.

Moryani, A.A., Rajput, N., Rajput, M.N. and Shah, A.H. (2020). Prevalence of common poultry diseases in chicken and influence of different medicinal herbs on growth of broiler chicken. Pure and Applied Biology 9(1): 1199-1208. DOI: 10.19045/bspab.2020.90126.

Nabinejad, A. (2013). Study of subclinical and clinical Marek's disease (MD) in the broiler chicken using histopathology. International Journal of Advanced Biological and Biomedical Research 1(8): 795-801.

Nair, V. (2018). Spotlight on avian pathology: Marek's disease. Avian Pathology 47(5): 440-442. DOI: 10.1080/03079457.2018.1484073.

Schat, K.A. and Nair, V. (2008). Marek's Disease. In: Y.M. Saif, A.M. Fadly, G.R. Glisson, L.R. McDoulgald LR, L.K. Nolan and D.E. Swayne (Eds.), Diseases of Poultry, 12 ed. Iowa: Blackwell Publishing Pp. 452514.

Schat, K.A. (1981). Role of the spleen in the pathogenesis of Marek's disease. Avian Pathology 10(2): 171-182. DOI: 10.1080/03079458108418471.

Sun, G-r., Zhang, Y-p., Lv, H-c., Zhou, L-y., Cui, H-yu., Gao, Y-1., Qi, X-1., Wang, Y-q., Li, K., Gao, L., Pan, Q., Wang, X-m. and Liu, C-j. (2017). A chinese variant
Marek's disease virus strain with divergence between virulence and vaccine resistance. Viruses 9(4): 71-81. DOI: $10.3390 / \mathrm{v} 9040071$.

Wen, Y., Huang, Q., Yang, C., Pan, L., Wang, C., Ki, K. and Liu, H. (2018). Characterizing the histopathology of natural co-infection with Marek's disease virus and subgroup $\mathrm{J}$ avian leucosis virus in egglaying hens. Avian Pathology 47(1): 83-89. DOI: 10.1080/03079457.2017.1375079.

Witter, R.L., Sharma, J.M., Solomon, J.J. and Champion, L.R. (1973). An age-related resistance of chickens to Marek's disease: some preliminary observations. Avian Pathology 2(1): 43-54. DOI: 10.1080/03079457309353780. 